\title{
Correction: Conditions, pathogenesis, and progression of diabetic kidney disease and early decliner in Japan
}

Yoshida Y, Kashiwabara K, Hirakawa Y, et al. Conditions, pathogenesis, and progression of diabetic kidney disease and early decliner in Japan. BMJ Open Diab Res Care 2020;8:e00902. doi: 10.1136/bmjdrc-2019-000902

This article was previously published with an error.

1. The formula for predicting the rate of lowering speed of eGFR at $\mathrm{T}$ years later in trajectory analysis was incorrect (Results, P6, line 3).

In the actual data, $T$ was calculated as a value of 1 (baseline) to 5 instead of 0 to 4 . Correct: $3.5 \times(\mathrm{T}+1)-16$

Incorrect: $3.5 \times \mathrm{T}-16$

2. The eGFR value 4 years after from baseline of the early decliner predicted by trajectory analysis was incorrect (Discussion, P7, line 14).

The formula predicted by trajectory analysis for predicted eGFR after $\mathrm{T}$ years is below (not shown in manuscript):

$\mathrm{F}(\mathrm{T}+1)=13.560539-15.968622 *(\mathrm{~T}+1)+1.767836 *(\mathrm{~T}+1)^{2}$

The eGFR value after 4 years is derived to be $-22 \mathrm{~mL} / \mathrm{min} / 1.73 \mathrm{~m}^{2}$, which is in agreement with the results shown in the figure 2 (P5).

Correct: $-22 \mathrm{~mL} / \mathrm{min} / 1.73 \mathrm{~m}^{2}$

Incorrect: $-29 \mathrm{~mL} / \mathrm{min} / 1.73 \mathrm{~m}^{2}$

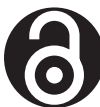

\section{OPEN ACCESS}

Open access This is an open access article distributed in accordance with the Creative Commons Attribution Non Commercial (CC BY-NC 4.0) license, which permits others to distribute, remix, adapt, build upon this work noncommercially, and license their derivative works on different terms, provided the original work is properly cited, appropriate credit is given, any changes made indicated, and the use is non-commercial. See: http://creativecommons. org/licenses/by-nc/4.0/.

(C) Author(s) (or their employer(s)) 2020. Re-use permitted under CC BY-NC. No commercial re-use. See rights and permissions. Published by BMJ.

BMJ Open Diab Res Care 2020;8:e000902corr1. doi:10.1136/bmjdrc-2019-000902corr1

A) Check for updates 